\title{
Autonomous Learning Levels of Students Majoring in EFL and the Role of their Teachers in Developing Autonomous Learning
}

\author{
Anwar Abdelrazeq* \\ Birzeit University, Palestine
}

Received: $21 / 2 / 2018$

Accepted: 2/5/2018

\begin{abstract}
Learning a foreign language is greatly enhanced when learners are autonomous and enjoy a high level of autonomy in a myriad of activities. The current study investigated the levels of autonomy among senior non-native English students and the role of their university instructors in promoting autonomous learning. More specifically, the study examined the autonomous learning levels of 4 th year non-native English majors and the role that the university instructors are playing in developing these non-native English majors' autonomous levels from students' perspectives. The data was gathered by semi-structured interviews. The sample of the study consists of 30 out of 100 students. Data collected were analyzed qualitatively using the thematic analysis method. The results of the study showed that generally non-native English majors enjoy a high level of autonomy in some activities ranging from the beginning to intermediate level. Pertaining to their instructors' roles in developing and improving their level of autonomy, the results showed that some students do not consider it a teacher's responsibility, whereas others indicated that it is incumbent upon the instructors to guide and train students on how to be autonomous and improve their level of autonomy. The reasons behind the results of the study, implications and recommendations for non-native English majors and university instructors are discussed.
\end{abstract}

Keywords: TEFL, autonomy, autonomous levels, autonomous activities.

\section{مستويات طلبة تخصص اللغة الانجليزية كلغة اجنبية يف التعلم المستقل ودور معلميهم ف2 تطويرها}

$$
\text { جامعة بيرزيت، فلسطبـ أنور عبدر }
$$

مستخلص: بحثت الدراسة الحالية مستويات طلبة تخصص اللغة الانجليزية كلفة أجنبية بِّ التعلم المستقل ودور معلميهم الجامعيين بِّ تعزيز

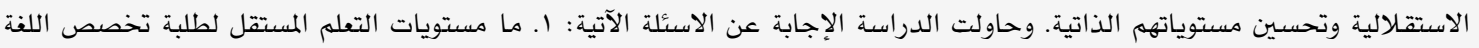

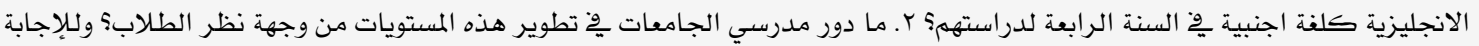

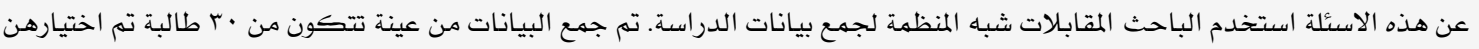

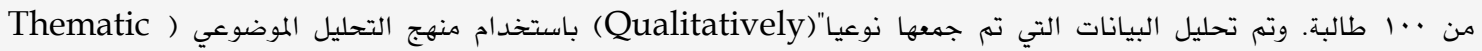

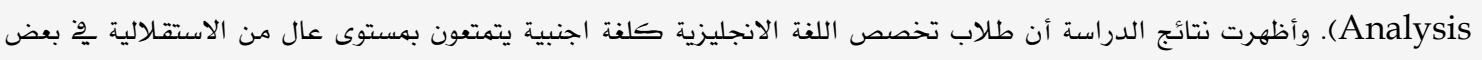

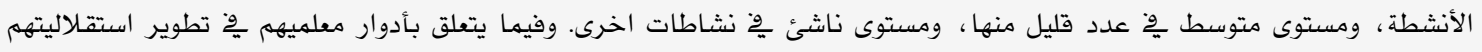

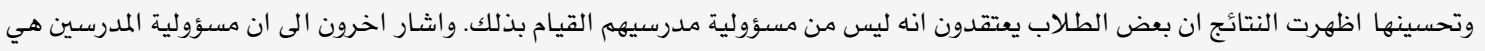

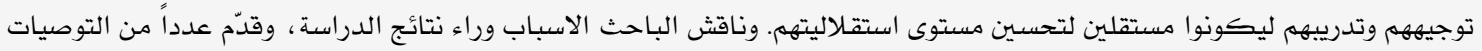
للمتخصصين يوٌ اللغة الانجليزية كلغة اجنبية ومدرسيهم. الكلمات المفتاحية : تعليم اللغة الانجليزية كلغة أجنبية، التعلم الذاتي، مستويات التعلم الذاتي، انشطة التعلم الذاتي.

*aaabdelrazeq@birzeit.edu 
"If the teacher is indeed wise, he does not bid you enter the house of his wisdom, but rather leads you to the threshold of your own mind" (Gibran, 1991, P.76)

The concept of autonomy has become a significant issue in teaching and learning. Autonomous learning becomes even more important in learning a foreign/second language. What English as a foreign language teachers do in the classroom is not enough to assist learners develop a high command in English. To achieve a high level in learning a foreign language, learners are required to be independent learners who continue to learn outside the classroom on their own. Accordingly, the ultimate goal of foreign language teaching should be training foreign language learners to become independent autonomous learners.

Many researchers and educators believe that autonomy could be measured in terms of levels (Benson, 2006). Such a notion led to the design of dynamic models that makes it possible to assess learners' autonomy taking into account that levels of autonomy are changeable. Everhard and Murphy (2015) argue that approaches in literature regarding the measurement, assessment and enhancement of learner autonomy vary according to the conceptualization of learner autonomy, the teaching and learning contexts, and the methods (qualitative, quantitative, combination of both) adopted to assess learner autonomy.

Assessing learner autonomy is challenging. Such challenges include technical problems and conceptual problems. Technical problems are related to the complexity of the notion and the construct of autonomy, which means that it should be possible to measure the autonomy of learners when the notion of autonomy and its construct are operationalized and conceptualized. If it is possible to think of autonomy as a 'measurable' aspect then it is possible to treat it as a matter of degree (Murase, 2015).

A dynamic model for measuring learner autonomy was developed by Tassinari (2015). In developing her model, she took into account a number of principles. These are the interrelationship between learning process dimensions, learning behaviors suitable for different contexts, the non-linear improvement of learner autonomy, the relationship between learner autonomy and performance in language, and the necessity of integrating learner autonomy assessment with suitable pedagogical practices. Tassinari's dynamic model consists of a cognitive and metacognitive component (e.g. awareness, learners' beliefs), an affective and motivational component (e.g. learners' feelings and willingness), an action-oriented component (e.g. skills, behaviors), and a social component (e.g. learning and negotiating learning with others).

\section{Contextual Background of the Study}

English is the main foreign language taught in the Occupied Palestinian Territories (OPT). Palestinian students learn English as a foreign language for 12 years (Grades 1-12) before they join Higher Education Institutions. Some students choose to major in English at university. The majority of these students are females. The requirements for majoring in English require a high average (90 - 93 out of 100) in the secondary school general exams called Tawjifi. Tawjihi is the general secondary exam taken by all students at the end of grade 12 in all subject areas taught at that grade level. Students usually take 10 exams in 10 subjects. Each subject has a score out of 100. A students' average in the Tawjihi is the total number of marks achieved in each subject divided by 10 (the number of subjects in which the student was examined).

Knowing the Tawjihi average required to major in English is vital. It informs us about the type of students who choose to major in English at university. These students are considered in the top $10 \%$ of all students who take the Tawjihi each year. Thus, these students are high academic performers based on their academic achievement. One could assume that these students are intelligent, motivated and hard workers. Choosing to major in English and mastering the English language demands a huge effort on the part of learners inside and outside classrooms. Only autonomous learners continue learning English on their own in addition to what they learn in formal classrooms at the university. 


\section{Research Questions}

The study attempted to answer the following research questions:

1. What are the autonomous learning levels of $4^{\text {th }}$ year English major university students?

2. What is the role of university instructors in developing their autonomy from students' perspectives?

Identifying learners' levels of autonomy and their instructor's role in developing and improving them is worth investigation. There are no research studies available on this topic. By conducting the current study focusing on nonnative English students majoring in English, the researchers hope that the results will shed some light on this significant issues encouraging other researchers to conduct similar studies in different educational contexts on all types of English learners. Identifying students' autonomous levels and their instructor's role in enhancing them is expected to create autonomous English language learners. The rubric designed and used by the authors in the current study will assist in such identification.

\section{Literature Review}

The issue of learner autonomy recently gained researchers' attention internationally. At the International Association of Teaching English as a Foreign Language (IATEFL), the learner autonomy special interest group (SIG) is considered each year as one of the main themes at the annual conference. Researchers interested in learner autonomy (LA) conducted research on a myriad of topics related to autonomous learning. Some of these issues are readiness for language learning autonomy, learners' beliefs and behaviors, the role of culture and students' attitudes, perspectives and understanding of autonomous learning practices. Other researchers focused on teachers. Lack of teachers' confidence in their students' ability to be autonomous, teachers' practices and perceptions in enhancing learners' autonomy and teachers' readiness and awareness were among the topics investigated.

\section{Readiness for Autonomy}

Some researchers investigated the readiness of language learners for autonomous learning. For instance, Hozayen (2009) studied the read- iness of freshmen students for language learning autonomy. Using a questionnaire, he collected data about role of the teacher, role of the students and the importance of feedback. The researcher concluded that time and constrains which resulted from the learners' tight timetables prevent them from practicing more of the language being learned in informal contexts. He recommended that teachers encourage learners to use autonomous learning strategies in order to become creative and autonomous learners.

Cotterall (1995) argued that it is necessary to measure learners' readiness for change in their beliefs and behaviors. She collected her data using a survey from a sample of adult ESL learners taking into account a number of factors: role of the teachers, role of feedback, learner independence, learners' confidence in their study ability, experience of language learning and approach to study. The study concluded that language learners' beliefs affect and may inhibit learners' acceptance and engagement in the language class activities. She also concluded that teachers and learners should be aware of the roles they play in the language learning process and that this awareness is the "pole" of autonomy.

Readiness and awareness are required when learners try to improve their ability to take responsibility of their learning process. In order to be able to go through the components of Tassinari's (2015) dynamic model, which is adopted in the current study, learners need to be aware of the way they would plan, cooperate, evaluate, monitor, structure knowledge, complete tasks, choose materials, deal with their feelings and motivate themselves. Some researchers believe that readiness and awareness are somehow related to culture. Ho and Crookall (1995) shed light on the Chinese culture and its effects on learner autonomy in English language teaching. They suggest that learners need to redefine their attitudes and views about the roles of teachers and learners in the learning process. They claim that teachers should help learners take responsibility for their own learning, taking into account the culturally constructed nature of the classroom setting. Learners participated in the 'stimulation' that aimed to provide them with an opportunity to take responsibility for their learning by deciding to engage in the stimulation, taking responsibility of the stimulation tasks 
and taking responsibility of learning and use of skills necessary. The results show that the participants keenly dealt with people from different cultures, became critical thinkers and learned to argue and write effectively and rationally. Thus, they took greater responsibility for their own learning. So, is it important to promote autonomy among learners?

\section{Importance of Learner Autonomy}

A two-phase study by Cooker (2012) addressed the debate on the importance of learner autonomy. In the first phase, the study explored the relationship between assessment and language learning autonomy. A survey was used to collect data from forty-five participants in thirteen countries. Results showed that language learning autonomy is widely assessed by a variety of tools. In the second phase, he collected data from thirty participants using interviews. Interviewees expressed their perceptions on the non-linguistic outcomes of learning in an environment in which autonomy is supported. The findings showed that there are six modes of autonomy: a love of languages, oozing confidence, socially oriented and enthusiastic, love of language learning, teacher-focused and competitively driven.

Some other studies focused on the same issue discussing the reasons why it is important to enhance learning autonomy. For instance, Dam (2011) provided insights into secondary school learners' autonomy. He discussed some reasons for improving autonomy among school-aged learners. He also outlined essential principles related to the implementation of autonomy in language teaching and learning. Moreover, he described how such principles could be practiced in an institutional context. As a result of the study, Dam listed a number of positive results for developing learner autonomy. These results include developing enhanced self-esteem, preparing for life-long learning and learning how to be responsible for one's own learning. However, he mentioned some pitfalls that should be avoided in implementing autonomous learning. Such pitfalls include: lack of teachers' confidence in their students' ability to be responsible for their learning, forgetting about being authentic, teaching instead of supporting learning and finding excuses for not being able to enhance autonomy among language learners.

\section{Teachers' Beliefs and Practices}

Lack of teachers' confidence in their students' ability to be autonomous was investigated by Aliponga et al. (2002). They studied the students rating of a three-stage model of skill learning: verbalization (requires teachers to provide new materials or skills that can be easily understood by students), automatization (students are engaged in meaningful activities), and autonomy (students can improve on their own). The researcher collected the data from 107 university students using a questionnaire. They concluded that teachers should aim high when implementing the three-stage process and believe in its importance in enhancing autonomy.

Another study by Borg and Al-Busaidi (2012) examined beliefs and practices of English language teachers regarding learner autonomy. Results of the study showed that teachers were disposed to the concept of autonomy. Their definitions of learner autonomy revealed support for concepts and notions such as choice, independence, control, freedom and responsibility. Most of them see autonomy as a set of abilities. Findings also showed that there is a gap between what teachers believe about learning autonomy and the feasibility of letting students participate in making decisions related to their learning process. There was also a gap between teachers' beliefs regarding developing students' autonomous skills and the feasibility of applying this on the ground. However, most of the teachers who participated in the study claimed they enhance autonomy among learners.

A similar study by Dwee and Anthony (2017) examined English teachers' practices and perceptions in enhancing learning autonomy among university students in Malaysia. Semistructured interviews were conducted to collect data from participants who were five English language teachers. Findings show that there is a lack of focus on improving students' autonomy in English classrooms because of a lack of teachers' readiness, passive attitudes towards students, and the timing and relevance of courses within the university curriculum.

The issue of teachers' readiness and awareness of enhancing autonomy among their students was studied thoroughly by a number of re- 
searchers. For instance, Griva and Chostelidou (2017) investigated the role of language awareness issues and teachers' beliefs and perspectives about language learning. Data was collected using a questionnaire from 150 EFL teachers teaching at public schools in Greece. Results showed that EFL teachers are, to a certain degree, conscious of the importance of raising awareness among EFL students and improving students' language learning strategies.

\section{Learners' Attitudes and Perspectives towards Autonomy}

Other researchers tended to shed light on students' attitudes, perspectives and understanding of autonomous learning practices. Bekleyen and Selimoğlu (2016) examined students' behaviors and perspectives about language learning autonomy at the university level in Turkey. It was conducted during the 2013-2014 academic year undergraduates and participants featured 171

Findings showed that students believe teachers should be responsible for choosing materials and activities in English classrooms and that course planning is a teacher responsibility. Students think they need their teachers' assistance and guidance in the learning process. Results also showed that students prefer some activities such as watching movies and TV programs and listening to English songs more than writing letters or diaries in English.

Orawiwatnakul and Wichadee's (2017) conducted a study that aimed at investigating beliefs of undergraduates about autonomous language learning. Results revealed that students had a high level of beliefs about language learning autonomy. However, outside the classroom, language-learning behaviors were at a moderate level. It was concluded that there is a relationship between beliefs about language learning autonomy and English proficiency, attitudes towards English learning, gender and students' language learning behaviors out of class. The researchers recommended that responsibilities should be shared between teachers and students.

\section{Method}

\section{Research Design}

This is a qualitative research study. Data collected were analyzed using the qualitative thematic analysis method (Braun, and Clarke,
2006). The study was conducted in the spring of the 2016 -2017 school year. The total population of the study was $1004^{\text {th }}$ year non-native English students. The sample was a convenient sample that consisted of 30 students. They were enrolled in "Teaching English as a Foreign Language II", course number 'EDUC $4302^{\prime}$. The course is required for all students who are planning to become English as foreign language teachers after graduation. All participants were in their final year at the university. They have been studying English at the university for 4 years. All the participants in the study were female students. Their ages ranged from 21 to 23 years old.

\section{Instruments and Materials}

The current study used the semi-structured interview for data collection. The researcher interviewed the 30 participants individually. Each interviews lasted approximately 45 minutes. The interviews were guided by a list of interview questions developed in advance (see Appendix A for the list of the questions). To ensure instrument validity and the appropriateness of the items on the instrument three specialists in the content of the instrument, reviewed the list of the interview questions. The researchers revised the instrument based on their suggestions. The interviews with the participants focused on their autonomous learning activities, how often they perform them and the role of the university professors in encouraging and developing students' autonomy. The researcher secured participants' consents, then recorded each interview. Later all interviews were transcribed resulting in a huge amount of data.

\section{Data Analysis}

Data collected were analyzed using Braun and Clarke's (2006) thematic analysis six-phase approach. In the first phase, the researchers familiarized themselves with the data. Transcribing the recorded data allowed the researchers to become familiar with it. In the second phase of the data analysis, a number of initial codes were identified. Codes were generated manually around particular questions in mind. In the third phase, codes were classified and sorted in initial themes. In the fourth phase, the researchers reviewed the initial identified themes resulting in some deletion and addition of new themes. After a thorough and detailed review of the themes, the re- 
searchers ended with a list of themes that focused on answering the research questions. In the fifth phase, themes were reviewed repeatedly in order to give them suitable labels according to their specifications and characteristics. After labeling themes and sub-themes it became possible to create good, clear themes which made it possible to look at the data critically and to start interpreting the results. In the last phase, the researchers presented the results of the study in a coherent and organized manner that assisted in answering the research questions of the study.

Table 1

Students' Autonomous Levels Rubric

\begin{tabular}{|c|c|c|c|c|}
\hline $\begin{array}{l}\text { Autonomous } \\
\text { Activity }\end{array}$ & Advanced Level & Intermediate Level & Beginning Level & Emerging \\
\hline $\begin{array}{l}\text { Motivating } \\
\text { oneself }\end{array}$ & $\begin{array}{l}\text { Learners always have } \\
\text { the will to learn auton- } \\
\text { omously. They always } \\
\text { motivate themselves. }\end{array}$ & $\begin{array}{l}\text { Learners sometimes } \\
\text { have the will to learn } \\
\text { autonomously. They } \\
\text { sometimes motivate } \\
\text { themselves. }\end{array}$ & $\begin{array}{l}\text { Learners rarely have the } \\
\text { will to learn autono- } \\
\text { mously. They rarely } \\
\text { motivate themselves. }\end{array}$ & $\begin{array}{l}\text { Learners never have the } \\
\text { will to learn autono- } \\
\text { mously. They never } \\
\text { motivate themselves. }\end{array}$ \\
\hline $\begin{array}{l}\text { Controlling } \\
\text { one's feelings }\end{array}$ & $\begin{array}{l}\text { Learners always effec- } \\
\text { tively control their feel- } \\
\text { ings while learning }\end{array}$ & $\begin{array}{l}\text { Learners sometimes } \\
\text { effectively control their } \\
\text { feelings while learning }\end{array}$ & $\begin{array}{l}\text { Learners rarely effec- } \\
\text { tively control their feel- } \\
\text { ings while learning }\end{array}$ & $\begin{array}{l}\text { Learners never effective- } \\
\text { ly control their feelings } \\
\text { while learning }\end{array}$ \\
\hline $\begin{array}{l}\text { Recognizing } \\
\text { one's own needs } \\
\text { and setting } \\
\text { goals }\end{array}$ & $\begin{array}{l}\text { Learner always recog- } \\
\text { nizes one's own needs, } \\
\text { formulate them into } \\
\text { realistic learning objec- } \\
\text { tives, and structure } \\
\text { them into steps and } \\
\text { create a learning plan }\end{array}$ & $\begin{array}{l}\text { Learner sometimes rec- } \\
\text { ognizes one's own } \\
\text { needs, formulate them } \\
\text { into realistic learning } \\
\text { objectives, and structure } \\
\text { them into steps and } \\
\text { create a learning plan }\end{array}$ & $\begin{array}{l}\text { Learner rarely recog- } \\
\text { nizes one's own needs, } \\
\text { formulate them into } \\
\text { realistic learning objec- } \\
\text { tives, and structure } \\
\text { them into steps and } \\
\text { create a learning plan }\end{array}$ & $\begin{array}{l}\text { Learner never recogniz- } \\
\text { es one's own needs, } \\
\text { formulate them into } \\
\text { realistic learning objec- } \\
\text { tives, and structure } \\
\text { them into steps and } \\
\text { create a learning plan }\end{array}$ \\
\hline $\begin{array}{l}\text { Choosing mate- } \\
\text { rials and meth- } \\
\text { ods }\end{array}$ & $\begin{array}{l}\text { Learner always chooses } \\
\text { and works with suitable } \\
\text { learning materials, } \\
\text { methods and strategies }\end{array}$ & $\begin{array}{l}\text { Learner sometimes } \\
\text { chooses and works with } \\
\text { suitable learning materi- } \\
\text { als, methods and strate- } \\
\text { gies }\end{array}$ & $\begin{array}{l}\text { Learner rarely chooses } \\
\text { and works with suitable } \\
\text { learning materials, } \\
\text { methods and strategies }\end{array}$ & $\begin{array}{l}\text { Learner never chooses } \\
\text { and works with suitable } \\
\text { learning materials, } \\
\text { methods and strategies }\end{array}$ \\
\hline $\begin{array}{l}\text { Completing } \\
\text { tasks }\end{array}$ & $\begin{array}{l}\text { Learner always organiz- } \\
\text { es time to learn and } \\
\text { completes tasks. }\end{array}$ & $\begin{array}{l}\text { Learner sometimes or- } \\
\text { ganizes time to learn and } \\
\text { completes tasks. }\end{array}$ & $\begin{array}{l}\text { Learner rarely organizes } \\
\text { time to learn and com- } \\
\text { pletes tasks. }\end{array}$ & $\begin{array}{l}\text { Learner never organizes } \\
\text { time to learn and com- } \\
\text { pletes tasks. }\end{array}$ \\
\hline Reflecting & $\begin{array}{l}\text { Learner always reflects } \\
\text { on topics, tasks, learning } \\
\text { process, and thinks } \\
\text { about oneself as a learn- } \\
\text { er. }\end{array}$ & $\begin{array}{l}\text { Learner sometimes re- } \\
\text { flects on topics, tasks, } \\
\text { learning process, and } \\
\text { thinks about oneself as a } \\
\text { learner. }\end{array}$ & $\begin{array}{l}\text { Learner rarely reflects } \\
\text { on topics, tasks, learning } \\
\text { process, and thinks } \\
\text { about oneself as a learn- } \\
\text { er. }\end{array}$ & $\begin{array}{l}\text { Learner never reflects } \\
\text { on topics, tasks, learning } \\
\text { process, and thinks } \\
\text { about oneself as a learn- } \\
\text { er. }\end{array}$ \\
\hline Self - evaluation & $\begin{array}{l}\text { Learner always evalu- } \\
\text { ates his / her competen- } \\
\text { cies and progress. }\end{array}$ & $\begin{array}{l}\text { Learner sometimes eval- } \\
\text { uates his / her compe- } \\
\text { tencies and progress. }\end{array}$ & $\begin{array}{l}\text { Learner rarely evaluates } \\
\text { his / her competencies } \\
\text { and progress. }\end{array}$ & $\begin{array}{l}\text { Learner never evaluates } \\
\text { his / her competencies } \\
\text { and progress. }\end{array}$ \\
\hline Cooperating & $\begin{array}{l}\text { Learner always learns } \\
\text { with and from others. }\end{array}$ & $\begin{array}{l}\text { Learner sometimes } \\
\text { learns with and from } \\
\text { others. }\end{array}$ & $\begin{array}{l}\text { Learner rarely learns } \\
\text { with and from others. }\end{array}$ & $\begin{array}{l}\text { Learner never learns } \\
\text { with and from others. }\end{array}$ \\
\hline $\begin{array}{l}\text { Managing one's } \\
\text { own learning }\end{array}$ & $\begin{array}{l}\text { Learner always connects } \\
\text { all aspects of the learn- } \\
\text { ing process and summa- } \\
\text { rizes important steps } \\
\text { and phases of autono- } \\
\text { mous learning from } \\
\text { other areas }\end{array}$ & $\begin{array}{l}\text { Learner sometimes con- } \\
\text { nects all aspects of the } \\
\text { learning process and } \\
\text { summarizes important } \\
\text { steps and phases of au- } \\
\text { tonomous learning from } \\
\text { other areas }\end{array}$ & $\begin{array}{l}\text { Learner rarely connects } \\
\text { all aspects of the learn- } \\
\text { ing process and summa- } \\
\text { rizes important steps } \\
\text { and phases of autono- } \\
\text { mous learning from } \\
\text { other areas }\end{array}$ & $\begin{array}{l}\text { Learner never connects } \\
\text { all aspects of the learn- } \\
\text { ing process and summa- } \\
\text { rizes important steps } \\
\text { and phases of autono- } \\
\text { mous learning from } \\
\text { other areas }\end{array}$ \\
\hline $\begin{array}{l}\text { Structuring } \\
\text { knowledge }\end{array}$ & $\begin{array}{l}\text { Learner always struc- } \\
\text { tures all autonomous } \\
\text { learning phases and } \\
\text { activities. }\end{array}$ & $\begin{array}{l}\text { Learner sometimes } \\
\text { structures all autono- } \\
\text { mous learning phases } \\
\text { and activities }\end{array}$ & $\begin{array}{l}\text { Learner rarely structures } \\
\text { all autonomous learning } \\
\text { phases and activities }\end{array}$ & $\begin{array}{l}\text { Learner never struc- } \\
\text { tures all autonomous } \\
\text { learning phases and } \\
\text { activities }\end{array}$ \\
\hline
\end{tabular}




\section{Results}

Data analysis yielded ten (10) major themes pertaining to students' autonomous learning. The researchers developed a rubric that described students' levels for each autonomous activity as shown in Table 1: Students' autonomous levels rubric. Students' levels included advanced level, intermediate level, beginning level and emerging level. Students at the advanced level always do the autonomous activity, students at the intermediate level some- times do the activity, students at the beginning level rarely do the autonomous activity and those at the emerging level never do the activity.

The rubrics were developed based on Tassinari's (2010) description of each activity. Based on participants' responses regarding how often they practice each activity, the modifiers always, sometimes, rarely and never were used to determine the participants' levels.

Table 2

Rank Order of the Eight Autonomous Activities as Practiced by the Participants

\begin{tabular}{ll}
\hline \multicolumn{1}{c}{ Activity } & \multicolumn{1}{c}{ Frequently Practiced by Participants } \\
\hline Motivating Oneself & 17 participants reported that they always practice this activity \\
Choosing materials and methods & 15 participants reported that they always practice this activity \\
Cooperating & 8 participants reported that they always practice this activity \\
Controlling one's feelings & 7 participants reported that they always practice this activity \\
Recognizing one's own needs and setting goals & 6 participants reported that they always practice this activity \\
Reflecting & 6 participants reported that they always practice this activity \\
Self - evaluation & 6 participants reported that they always practice this activity \\
Managing one's own learning & 6 participants reported that they always practice this activity \\
Designing, Editing and Completing tasks & 5 participants reported that they always practice this activity \\
\hline
\end{tabular}

\begin{tabular}{|c|c|c|c|c|c|c|c|c|}
\hline \multicolumn{9}{|c|}{ Autonomous Students' Levels } \\
\hline \multicolumn{9}{|c|}{ Cooperating } \\
\hline \multicolumn{9}{|c|}{ Self-Evaluation } \\
\hline \multicolumn{9}{|c|}{ Reflecting } \\
\hline \multicolumn{9}{|c|}{ Designing, Editing and Completing Tasks } \\
\hline \multicolumn{9}{|c|}{ Choosing Materials and Methods } \\
\hline \multicolumn{9}{|c|}{ Recognizing One's Own Needs and Setting Goals } \\
\hline \multicolumn{9}{|c|}{ Controlling One's Feelings } \\
\hline \multicolumn{9}{|c|}{ Motivating Oneself } \\
\hline \multicolumn{9}{|r|}{30} \\
\hline & $\begin{array}{l}\text { Motivating } \\
\text { Oneself }\end{array}$ & $\begin{array}{l}\text { Controlling } \\
\text { One's } \\
\text { Feelings }\end{array}$ & $\begin{array}{c}\text { Recognizing } \\
\text { One's Own } \\
\text { Needs and } \\
\text { Setting Goals }\end{array}$ & $\begin{array}{c}\text { Choosing } \\
\text { Materials } \\
\text { and Methods }\end{array}$ & $\begin{array}{c}\text { Designing, } \\
\text { Editing and } \\
\text { Completing } \\
\text { Tasks }\end{array}$ & Reflecting & $\begin{array}{c}\text { Self- } \\
\text { Evaluation }\end{array}$ & Cooperating \\
\hline Advanced level & 17 & 7 & 6 & 15 & 5 & 6 & 6 & 8 \\
\hline Intermediate Level & 6 & 13 & 11 & 8 & 7 & 18 & 13 & 14 \\
\hline Beginning Level & 3 & 2 & 7 & 4 & 12 & 6 & 3 & 8 \\
\hline Emerging & 4 & 8 & 6 & 3 & 6 & 0 & 8 & 0 \\
\hline
\end{tabular}

Figure 1

Number of the Participants at Each Level 
In determining the number of participants at each level, the researchers used the modifiers always, sometimes, rarely and never as used by the participants in answering the interview questions. For instance 17 of the participants reported that they always motivate themselves, six participants reported that they sometimes motivate themselves, three participants stated that they rarely motivate themselves and four said they never motivate themselves. The number of each participant for each level determined in the same manner.

Further, to ensure the rubric's validity, three specialists in the EFL field reviewed the description of each activity. Below is a detailed description of each autonomous activity (Theme) and the levels of students in that activity. In addition, Figure 1: Number of students at each Level below shows how many students at each level for each autonomous activity. A rank order for the eight autonomous activities is shown in Table 2. Table 2 shows the activities that are practiced often and the activities that are practiced less often by the participants.

\section{Autonomous Learning Activities: Motivating One's Self}

Twenty $(66 \%)$ of the participants reported that they always motivate themselves to learn English independently. To motivate themselves, they engaged in a variety of practices. Such practices include using interesting materials (e.g. reading short stories and exciting online articles), listening to songs, watching movies, funny TV shows and series, learning with other students. "I try to choose materials that interest me. I also motivate myself by learning with other students" as R1 (Respondent \#1) stated. Listening to native speakers, attending workshops, writing about interesting issues are other practices used. R2 said, "I write about interesting issues. I use interesting materials".

Other activities that the participants mentioned to motivate themselves include imagining instructors that motivate them, loving the language. "I don't know. it's an internal motivation... I love the language and I really want to improve myself," R4 stated. The desire to learn English because it is a prestigious and universal language. In the words of R6:
English is an international language! All people around the world understand this language ... learning this language can help me interact with people around the world .. China .. India .. Somalia! Everywhere.

Further, extrinsic factors affect learners' motivation. Twenty participants $(66 \%)$ stated they want to learn English in order to be able to get a good job and communicate in English. R8 reported, "I need to get a good job. I want to be able to communicate with the whole world! English is dominating the world". Further, R 12 sated;

My brother speaks English fluently and he keeps making fun of me of my speaking. I really want to be like him! I want to improve my writing, and my speaking. I want to be like native English speakers.

On the other hand, 4 (13\%) of the participants stated that they are not motivated. They are not able to learn independently. They prefer to depend on their instructors. "I can't learn English independently. teachers know what we need to learn. They are professionals. They have a plan for us" in the words of R 15. R 18 admitted she knows she can learn English independently but she is not motivated and putting enough effort to improve this ability. She stated,

I know I can learn English independently but I don't put effort to do so. I want to tell you something! My father forced me to study English he said: "English or nothing", that's why I'm not that motivated. I like the language but I hate the way they teach it so boring!.

\section{Controlling One's Feelings}

Half of the participants (50\%) stated that they try to stay positive and try to get rid of negative feelings while learning English. They try to control negative feelings to prevent them from affecting their learning. In the words of $\mathrm{R}$ 16, "I control myself... I don't let people notice when I have negative feelings. if I surrender to such feelings I'll end up doing nothing". Some of the strategies that they use to control negative feelings are talking to their parents or teachers about the way they feel learning English, about their achievement, and the challenges they face. R 19 emphasized that feelings should be dealt with rationally. In her words, 
Aha! Negative and positive feelings should be treated rationally...if you let positive feelings make you lazy and arrogant then you're a LOSER! And similarly if negative feelings make you feel useless or good-for-nothing then you are also a LOSER! I try to control my feelings both positive and negative to be successful.

The other $15(50 \%)$ of the participants admitted they could not control their negative feelings that affect their learning. "Negative feelings such as hesitancy and fear are really affecting my learning," R 21 said. R 23 stated:

I can't control negative feelings. THEY CONTROL ME. I feel sad and blame myself! But when I feel satisfied for example, it's really good, it's motivating!.

\section{Recognizing One's Own Needs and Setting Goals}

Twenty five (83\%) of the participants reported they tend to depend on teachers' evaluation and needs assessment. "Teachers evaluate my skills and analyze my needs... they know more than me! I don't know how to evaluate myself... they have rubrics, checklists and typical answers", in the words of R 26. Ten $(33 \%)$ of the participnats stated they are able to evaluate their language skills and analyze their needs. They use checklists and rubrics to assess their needs and improvement. R 29 stated;

I use checklists... I love checklists because they help you know what you have learned... what you have achieved and what you need to learn and improve. Sometimes teachers give us checklists and rubrics to evaluate ourselves... they also use rubrics to evaluate our writings.

When setting learning goals, those ten participants take into account: (a) their language skills and needs, (b) their learning competencies and preferences, (c) their learning styles, (d) materials they need to use, and (e) time and place. "My learning preferences and my needs. I also take into account the time I need to achieve my goals", in the words of R 28 .

\section{Choosing Materials and Methods}

Four $(13 \%)$ of the participnats could only be considered at an advanced level in choosing materails to help them learn and improve their English. This group of students use various kinds of materials and resources such as websites, movies, novels, songs, YouTube videos, summaries, magazines, stories, essays, books, textbooks, dictionaries, communicating with native and fluent speakers, TV shows and CDs. When choosing materials they take into account their goals and needs, learning style, skills, preferences, effectiveness of the materials and nature and goals of the assignment. The remaining partcipants follow the outline and use materials suggested by their instructors. "Teachers usually suggest materials and resources... according to the task." And "Teachers tell us which materials to use", in the words of R 23.

\section{Tasks Completion}

Only four $(13 \%)$ of the participants could be considered at the autonomous advanced level in this activity. They always organize their time to design and complete tasks. They design some tasks and complete them based on their needs and skills. R 22 put it this way;

I design and edit some tasks... I do not depend on the English courses I am taking at the university... I do other tasks to improve my language independently. Sometimes I perform tasks I find on English teaching websites.

Another four $(13 \%)$ participants reported that they partially design learning tasks and activities. They modify instructors' designed tasks and complete them as part of the course requirements. "Teachers design and edit tasks... but sometimes they allow us to make some changes", R 21 sated.

The remaining 22 (74\%) participants could be considered at the beginning level pertaining to this autonomous activity. They reported that they rarely design and complete tasks on their own. They follow instructors' instructions and perform what they ask them to do. "We don't have the chance to design or edit tasks... teachers give us tasks they designed", in the words of one of R 17. In addition R 15 stated, "I can't design or edit a task. We are not allowed to. We only complete previously designed tasks".

\section{Reflection}

All 30 participants (100\%) reported that they always reflected on themselves as foreign language learners. In particular, they always reflect exclusively on their strengths and weakness. Some of the strengths that they mentioned include remembering new words, writing good essays and reports, skimming and 
scanning, observing language structures and patterns, analyzing literary texts, preparing presentations and explaining issues, using the internet professionally and speaking clearly and confidently. Some of them talked about strengths in their personality such as self confidence and persistence, the ability to learn, ambitious and being self-motivated.

Twenty-five participants $(83 \%)$ reported that speaking is their major weakness. In the words of R 7:

Speaking! Mainly speaking! I do not have many opportunities to improve my language and I do not participate in the discussions. I am always afraid because my colleagues may make fun of me when I make mistakes.

Some of them added that they always reflect on ways to improve their pronunciation, listening comprehension, and writing. Few of them always reflect on how fear and lack of concentration are affecting their learning negatively.

\section{Self-Evaluation}

All the 30 participants $(100 \%)$ reported that they always evaluate their competencies and progress in improving their English. They believe they are not making major progress in improving language skills due to contextual and personal affective factors. Some of the contextual factors that are hindering their progress are the atmosphere at the university, the need for more-advanced courses, limited daily exposure to English, and a lack of opportunities to practice English. In the words of R 13, "The not motivating environment here at the university. They neglect low performing students". Fear of speaking and making mistakes, tension, low self-esteem, lack of selfconfidence, laziness, boredom, frustration and lack of motivation are some of the affective and personal factors that thwart participants from making progress. R 11 stated:

Honestly? Not putting so much effort to improve my language... not being motivated... and maybe caring too much about what people may think... I mean... their criticism.

\section{Cooperating}

Twenty of the participants $(67 \%)$ reported that they always learn with and from others. They stated that that cooperation helps them improve their language. They cooperate with others when planning, making presentations, selecting materials and resources. In the words of R9 commenting on when she cooperates with others "When selecting materials. it helps. more students. more ideas. variety in materials and resources". Participants reported that they cooperate with other learners when they prepare for exams and do a project or a task. On the other hand, the remaining ten participants (33\%) prefer individual work. They prefer to do tasks by themselves. "I prefer to do tasks individually," R19 stated.

\section{Instructors' Role in Developing Learners' Autonomy}

Participants' responses reflected two points of view about the teachers' role in assisting them in developing their autonomous learning levels to reach their highest desired one. Some of the participants $(24 \%)$ stated that it is not the instructors' responsibility to help them develop their autonomous learning levels. Some indicated that instructors do encourage them to improve their language and to become more creative. "Most of them encourage us to be creative... they encourage us to learn individually. to choose different materials and resources", in the words of R 3 . The problem, according to a number of participants, is their intrinsic motivation. R 14 stated, "They have to do nothing! If students do not have intrinsic motivation to learn the language independently NOTHING in the world can motivate them! ". Although teachers do encourage students, they are not putting in enough effort. R 24, emphasizing this point that students are not exerting the required effort, stated:

We are not kids! We can guide ourselves. We can motivate ourselves. We have the power and the ability. but we underestimate ourselves. We are lazy. It is easier to blame others... It is better to think rationally and to become active learners not passive.

On the other hand, many participants claim that teachers keep lecturing and do not motivate them to learn independently. "Most of the teachers keep lecturing... they keep talking! They do not motivate us to learn independently. We are passive most of the time", as one of the students put it.

In order to assist them to become autonomous and active learners they would like their in- 
structors to stop treating them as passive learners. R 25 said:

They [instructors] should stop treating us as passive objects! They want us to follow their directions and that's it... they don't want to get tired... it easier for them to treat us in the same way. That is why they do not allow us to participate in designing tasks and making evaluations".

They would like their instructors to let them participate in choosing the material, the resources required for some courses and participating in designing the learning tasks. From their perspective, this allows them to be active and improve their autonomous learning levels. In this regard, one of the students stated:

They should not force us to use particular materials and resources... especially the textbook! They should train us to look for information... to improve our skills and our knowledge individually. In literature classes they should allow us to analyze from our point of view not from their point of view. I think when we reach the point that we are able to explain what we have learned... then we are fully autonomous... We reach the highest desired lev$\mathrm{el}^{\prime \prime}$.

R 10 stated: They could encourage us to learn individually... They should give us the chance to design tasks and choose the materials... and I think it is a matter of choice ... if you choose to learn you learn.

R 30 emphasized: They should help us participate in projects and encourage us to choose interesting materials and resources, to become familiar with language learning strategies and methods... and to design and edit tasks.

To help them become autonomous learners some students would like their English instructors to let them work on projects rather than the mere provision of information. R 20 stated, "They should ask us to do projects not to memorize information and take exams". Other participants also emphasized differentiating the methods of instruction. "They should use more interesting and modern instructional methods... they need to stop lecturing and help us become active", in the words R 27. R 25 summarized this point succinctly:

Well... they should use various kinds of instructional methods to meet all students' preferences and learning styles. They should also encourage us to learn individually... to depend on ourselves... they should help us feel free to use the materials and methods we choose... to think... they want us to believe in their ideas... their points of view... their analysis... and that is really bad... and old-fashioned.

Further, the participants would like their instructors to stop spoon-feeding them. "They have to assist us to be creative and responsible for our learning. They spoon-feed us! Even when we want to be creative and think out of the box... some of them don't like it", in the words of R 17.

\section{Discussion}

The current study focused on finding the autonomous learning levels of a graduating class of non-native English speakers whose major is English language and literature. These students have been learning English as a foreign language for almost sixteen years. They learned English for 12 years at schools before they joined university. At the university level, they spent 4 years studying English as a specialization. The researchers found that the $83 \%$ of these graduating English majors enjoy a high level of autonomy in certain autonomous activities such as self-motivation, reflection, self-evaluation and cooperating with other learners. Also, $83 \%$ of participants are at the low level pertaining to needs awareness, setting goals and choosing material. Fifty percent of the participants were at the low level and $50 \%$ at the high level as far as self-control and choosing material/activities.

Two-third of the participants reported that it was their instructors' responsibility to improve and develop their autonomous levels. These participants would like their instructors to stop spoon-feeding them, engage them in the learning process, and design activities that promote autonomy such as working on projects individually and cooperatively. In addition, they recommended that their instructors differentiate instruction in a way that assists them to improve and develop their autonomous learning. This is in an agreement with Dam's (2011) finding that English teachers need to stop relying exclusively on lecturing. Instead, they need to differentiate instruction, design autonomous learning activities, support autonomous learning and have confidence in their students' ability to be autonomous. 
Palestinian English language majors are in dire need of training and instruction that develops and improves their autonomy and assists them to become life-long learners. To achieve this, university English language instructors need first to be aware of their students' autonomous levels and design activities and tasks that improve these levels. This is vital particularly for English majors who need to continue learning and improving their command of English after graduation. Most of these graduates will become English as Foreign Language (EFL) teachers. Continuous professional development in terms of content and pedagogy is essential for improving learners' English proficiency. In addition, a number of these graduates pursue graduate studies that require a high level of English proficiency in all language skills. Being an autonomous language learner who continues to improve his/her English language skills will definitely increase the chances of success at the graduate level.

The researchers believe that the present study is very informative and highlights vital issues of which university English professors and instructors in foreign contexts need to be aware. Foreign students who choose to major in English after high school require special and unique support and attention on the part of their university professors. The nature of the major (English) and the type of students who choose to major in a language other than their mother tongue is challenging. At least what we could do, as university English instructors, is reflect on our instructional practices in light of the results of the current study. Such reflection will assist all of us in designing classroom and outside classroom activities that aid our students to become autonomous, life-long learners after graduation. This is expected to have a great effect on the foreign language learners'. They will teach when they become teachers.

Having autonomous life-long English language learners who became EFL teachers will assist tremendously in creating school learners who have a strong command in English. Some of these high school graduates will pursue their undergraduate studies majoring in English. Having non-native English speakers who have already a high level in English is a great achievement. University English instructors could continue improving students' levels in English when they change their instructional practices to create autonomous language learners.

The reasons in the current study behind graduating English majors who have low autonomous learning levels in some of the autonomous activities such as self-control, needs assessment, choosing material and task completion described in the rubric might be attributed to various factors. These include leaners lack of practice and training in emotional intelligence. The unique stressful context in which learners live might also contribute to the absence of the ability of learners to control their feeling during the learning process. Having a low level in needs assessment and choosing learning material could be attributed to students' total reliance on teachers at schools and at the university in determining their educational needs and choosing the material and activities required to meet students' needs. The spoon-feeding, teacher-centered teaching methods and control of instructors of the learning process might be the reason behind having a low autonomous level in task completion.

Although the majority of participants have a low autonomous level in some of the autonomous activities, the majority of them also enjoyed a high level of autonomy in selfmotivation, reflection, self-evaluation, and cooperating with other learners. Such a high level in the aforementioned autonomous activities could be attributed to one main reason: university students who choose to major in English have an outstanding school academic achievement. The requirements to major in English are very demanding. Each year the English department accepts a limited number of students. Their 'Tawjihi' average is at least approximately 92 out of 100 .

The finding that learners depend on their instructors pertaining to needs assessment, evaluation and instruction is an agreement with Cotterall's (1995) conclusion that leaners' beliefs affect and may inhibit their approval and commitment to leaning autonomously. Palestinian learners believe that it is their instructors' responsibility to design, manage and implement the learning process. Palestinian non-native English majors are aware of their role and their instructors' roles in the learning 
process. This emphasizes the traditional way of teaching in the Palestinian education system where route learning, memorization and total dependence on teachers are the main and acceptable practices. That is why the vast majority of the participants in the study are unable to assess their language needs, choose materials that assist themselves in improving their English skills, and choose effective leaning tasks and activities.

Following the traditional way of teaching (lecturing) and the lack of motivating learners to be active and learn independently, supports Ho and Crookball's (1995) argument that the learning context plays a major role in taking responsibility over one's own leaning. Such a lack of confidence in Palestinian English learners' abilities to learn independently because they are used to the traditional way of teaching confirms Aliponga et al. (2002) conclusion that a lack of confidence has a major impact on developing autonomous learners.

A lack of confidence in learner ability exacerbated by a context that is driven by spoonfeeding teaching methodology requires deep and thorough reflection on one's teaching practices. As Dwee and Anthony (2017) found, the reasons behind participants low level in some autonomous activities might be their instructors' the lack of readiness, lack of having high expectations for students to be autonomous and independent learners. The researchers are not putting all the blame on the teachers. Nevertheless, they believe EFL teachers/instructors play a major role in inspiring, training and assisting learners in becoming autonomous.

It might be that Palestinian instructors' lack of readiness and Palestinian students' passive attitudes and roles towards autonomous learning are the reasons behind such prevailing teaching and learning practices in Palestine. This confirms Dwee and Anthony's (2017) conclusion that a lack of training and awareness prohibits and delays acceptance of autonomous learning roles and practices. The Palestinian educational context in which autonomy is not encouraged and supported will continue to have learners who entirely depend on their instructors.

Having learners who continue to rely on their teachers will definitely not graduate learners with high English proficiency. There is a strong relationship between learners' belief in autonomous learning and English proficiency as Orawiwatnakul and Wichadee (2017) state. Thus, to help Palestinian learners and other learners in similar contexts become autonomous learners, a radical change in learners beliefs, practices and attitudes is required. It is the instructors' responsibility to undertake such change immediately. Leading by doing and showing students how they themselves practice autonomous learning to improve their English proficiency might be the first step.

The results of the current study are unique to the Palestinian educational context. The researchers caution against generalizing the results to other contexts particularly those that have a different philosophy of education and culture. As we found in the current study, learners' beliefs and attitudes toward autonomy played a major role in accepting and adopting autonomous learning activities. In addition, the small sample size (30 participants) might limit the generalizability of the results to other populations. More research on the topic in Palestine and elsewhere at various educational levels is strongly recommended.

\section{Conclusion}

The current study investigated senior nonnative English students' autonomous learning levels and the role of their instructors in promoting autonomy and developing autonomous learners'. As the results of the study showed, learners are in dire need of training to be autonomous in certain areas even though they enjoy a high level of autonomy in areas such as motivation. Pertaining to the university instructors' role in enhancing and developing their students' autonomy, twenty-two of the participants reported that their instructors are not doing enough to train them to be autonomous. They would like their instructors to use student-centered teaching strategies and minimize lecturing and spoon-feeding

\section{Classroom Implications}

A number of classroom implications could be elicited from the current study. First, instructors should make students aware of the autonomous activities that they could perform to enhance their learning. Second, it is worth holding explicit training sessions on how to perform certain autonomous activities such as monitoring one's own learning, selfassessment, etc. Third, university instructors need to integrate autonomous learning strate- 
gies and activities in their classes to improve students' autonomous learning and autonomous levels. Fourth, differentiation of instruction and using a variety of student-centered teaching strategies will definitely contribute to training students to be autonomous and develop their autonomous levels.

\section{Recommendations for further Research}

Autonomous learning and learner autonomy are significant issues that worth investigating in various contexts. Some of the areas that researchers who interested in this area might investigate include the autonomous practices that K-12 EFL teachers use to promote learner autonomy among students. Second, finding K12 EFL teachers and university EFL instructors' autonomous learning strategies and autonomous learning levels is another issue that researchers might investigate. Third, the impact of Information Technology (IT) on learners' autonomy and the effective practices of IT in promoting autonomy among learners at all levels are other areas that researchers might investigate.

\section{References}

Aliponga, J., Gamble, C., \& Ando, S. (2011). Verbalization plus automatization plus autonomy: A simple formula for learner autonomy. Edited by David Gardner.

Birjandi, P., \& Bagherkazemi, M. (2010). The relationship between Iranian EFL teachers' critical thinking ability and their professional success. English language teaching, 3(2), 135.

Borg, S., \& Al-Busaidi, S. (2012). Learner autonomy: English language teachers' beliefsand practices. ELT Journal, 12(7), 1-45.

Braun, V., \& Clarke, V. (2006). Using thematic analysis in psychology. Qualitative Research in Psychology, 3(2), 77-101.

Cooker, L. (2012). Formative (self-) assessment as autonomous language learning (Doctoral dissertation, University of Nottingham).

Cotterall, S. (1995). Readiness for autonomy: Investigating learner beliefs. System, 23(2),195205.

Dam, L. (2011). Developing learner autonomy with school kids: Principles, practices, results. Edited by David Gardner.
Dwee, C. Y., \& Anthony, E. M. (2017). Learner Autonomy in University English Classrooms: Teachers' Perceptions and Practices. International Journal of Applied Linguistics and English Literature, 6(2), 19-25.

Everhard, C., \& Murphy, L. (Eds.). (2015). Assessment and autonomy in language learning. Springer.

Griva, E., \& Chostelidou, D. (2017). Language awareness issues and teachers' beliefs about language learning in a Greek EFL context. Selected papers on theoretical and applied linguistics, 19, 213-222

Ho, J., \& Crookall, D. (1995). Breaking with Chinese cultural traditions: Learner autonomy in English language teaching. System, 23(2), 235-243.

Hozayen, G. (2009). Are Arab maritime students ready to become autonomous language Learners? In Proceedings of the 21st international maritime English conference.

Lamb, T. (2001). Learner autonomy, teacher autonomy: Future directions. B. Sinclair, \& I. McGrath (Eds.). Longman.

Murase, F. (2015). Measuring language learner autonomy: problems and possibilities.In Assessment and autonomy in language learning (pp. 35-63). Palgrave Macmillan, London.

Orawiwatnakul, W., \& Wichadee, S. (2017). An Investigation of Undergraduate Students' Beliefs about Autonomous Language Learning. International Journal of Instruction, 10(1), 117-132.

Tassinari, M. G. (2011). Evaluating learner autonomy: A dynamic model with descriptors. Reading.

Tassinari, M. G. (2015). Assessing learner autonomy: A dynamic model. In Assessment and autonomy in language learning (pp. 64-88). Palgrave Macmillan, London. 


\section{Appendix A}

\section{Interview Questions}

\section{Autonomous learning Activities}

\section{A. Motivating Yourself}

1. How do you motivate yourself to learn English independently (e.g. rewards, interesting materials and projects...)?

2. What other things motivate you to learn English?

\section{B. Dealing with Feelings:}

1. How do you usually deal with your feelings and emotions (e.g. satisfaction, achievement, boredom, emotional blocks, fear of speaking or making mistakes...) while learning English as a foreign language?

\section{Planning}

1. How do you evaluate your language skills and analyze your needs?

2. What do you take into account when putting your own goals in language learning? (e.g. needs, skills, given conditions ...)

3. 3. What does your learning plan include? (e.g. goals, materials...)

\section{Choosing Materials and Methods}

1. What materials and methods do you use to learn English as a foreign language? (e.g. authentic materials, native speakers, websites ...)

2. What do you take into account when choosing materials for learning English?

\section{E. Completing Tasks}

1. How do you carry out your learning plan (possibly with appropriate modifications)? Please explain. For example by doing all or some of thefollowing:

a. Designing, editing and completing tasks

b. Using materials and resources

c. Analyzing Language structures and patterns

d. Dealing with texts, conversations ...
2. How do you manage the given conditions (e.g. time, place...) when completing a particular task?

\section{F. Monitoring}

1. What are your strengths and weaknesses as a language learner?

2. How do you observe your progress?

3. What do you think prevents you from making progress in particular English language areas?

\section{G. Evaluating}

1. How do you usually evaluate your learning progress and the materials, resources, methods and strategies you use to learn English? For example:

For progress: (goals achieved, goals match your language skills and needs ...) Materials and resources: (meet the objectives)

Methods and strategies (tasks correspond learning style, make learning effective and efficient)

\section{H. Cooperating}

1. How do you learn with and from others (e.g. fellow learners, teachers, language learning consultants, native speakers, competent non-native speakers)

2. When do you think it is more advantageous to perform a task in cooperation with others? (e.g. when planning, when selecting materials ...)

\section{Research Question \#4 (Open-ended Ques- tion):}

How university instructors could assist you in developing your autonomous learning levels to reach your highest desired level? 